\title{
The Great Recession and the New Frontiers of International Investment Law: the Economics of Early Warning Models and the Law of Necessity
}

\author{
Alberto Alvarez-Jimenez \\ Faculty of Law, University of Waikato, New Zealand \\ E-mail: aalvarez@waikato.ac.nz
}

\begin{abstract}
The Great Recession has prompted unparalleled economic research on the causes and handling of crises. It is then important for international investment law to catch up with the new conceptual developments. This article is an attempt in this direction. Its first part presents a description of one of the main tools to avoid economic collapsesearly warning models (EWMs) - which have received increasing attention by the European Central Bank, the International Monetary Fund (IMF), and the Fed. This part also presents the debate among economists about the meaningfulness of EWMs. The second part shows how international investment law should respond to this debate and proceed with an assessment of the role that EWMs may have in the interpretation of emergency clauses in BITs and the customary rule of necessity. In particular, this part deals with the question of what happens in international legal terms when a State, which relies on EWMs to adopt measures aimed at preventing a crisis, adversely affects foreign investors. The section also discusses the level of deference that investor/State tribunals may accord to States relying on EWMs when taking economic preventive action and illustrates how international arbitration tribunals should deal with debates on the quality of the given EWMs.
\end{abstract}

"Everything is fragmented and fluid and unstable and hopeful and dangerous. We have insights and connections and blank spaces and questions," said the Egyptian writer Ahdaf Soueif. ${ }^{1}$ While she refers to the Arab Spring, her words also apply to its contemporary opposite: the Western winter-the Great Recession, the current

1 Ahdaf Soueif, 'Mina's Banner. Edward Said and the Egyptian Revolution', London Review of Books, 15 June 2012, available at http://www.lrb.co.uk/2012/06/15/ahdaf-soueif/minas-banner (visited 15 January 2014).

(C) The Author 2014. Published by Oxford University Press. All rights reserved. 
financial crisis - and describe with accuracy the uncertainties and problems that the US and European governments have faced over the last six years.

Although economic crises have always existed, ${ }^{2}$ they were usually in the realm of emerging or developing economies, ${ }^{3}$ and the analyses and assessments of these events were, therefore, important but somehow limited. Not this time around. The ongoing Great Recession, fuelled by a significant degree of public oversight and deliberation, has prompted a breadth of unparalleled political and economic research in North America and Europe on the causes, consequences, and handling of the crisis. How will these new realities affect the interpretation of international investment law in treaties and customary international law (CIL)? Whilst litigation in the aftermath of Argentina's 2001 financial crisis triggered the revival and development of the international law of economic crises, it may not be an exaggeration to expect that, given its magnitude and the States affected, the Great Recession will take this evolutionary process much further and into areas unexplored before.

It is, then, important for international investment law to catch up with the conceptual developments in economics that the Great Recession is bringing about. This article is an attempt in this direction. ${ }^{4}$ There are, and there will be soon, other developments, so this piece does not pretend to exhaust the subject-matter. Quite the opposite, it seeks to indicate a path for others to continue exploring in the short and medium term.

This article is divided into three sections. Section I presents the research in economics on the extraordinary costs of economic crises, and it continues with a description of one of the main tools to avoid these events-early warning models (EWMs) - which have received increasing attention in the aftermath of the Great Recession. This section also presents a comparison between the performance of EWMs and other tools policy-makers use to anticipate economic crises as well as the debate among economists about the meaningfulness of EWMs. Section II includes an analysis of how international investment law should respond to this debate and proceeds with an assessment of the role that EWMs may have in the interpretation and application of non-precluded measures clauses in bilateral investment treaties (BITs) and the customary rule of necessity embodied in Article 25 of the International Law Commission's Articles on State Responsibility. ${ }^{5}$ Sections 3 presents the conclusions.

2 Vincent Reinhart, 'A Year of Living Dangerously: The Management of the Financial Crisis in 2008', 25 Journal of Economic Perspectives 71, 73 (2011).

3 In a more distant past, developed economies also experienced significant economic crises, starting with the U.S. Great Depression of 1929 and ending with the long Japanese crisis of the 1990s. For an assessment of common patterns of financial crises, see Carmen M Reinhart and Kenneth S Rogoff, 'Is the 2007 US SubPrime Financial Crisis So Different? An International Historical Comparison', 98 American Economic Review 339 (2008) [Reinhart and Rogoff, Sub-Prime Crisis].

4 This article can also be seen, to certain extent, as an expression of a recent trend in international law aimed at a more extended dialogue with other disciplines, such as economics and international relations. See in this regard, Gregory Shaffer and Tom Ginsburg, 'The Empirical Turn in International Legal Scholarship', 106 American Journal of International Law 1 (2012).

5 By such role, the present author means the possibility of making a causal claim in law based on EWMs. On the use of econometric models as evidence, see Ioannis Lianos and Christos Genakos, Econometric Evidence in EU Competition Law: An Empirical and Theoretical Analysis, Centre for Law, Economics and Society. 


\title{
I. DEVELOPMENTS IN ECONOMICS IN THE AFTERMATH OF THE GREAT RECESSION
}

\section{A. The Impacts of Economic Crises}

\section{"It was as though the world had awakened in the depths of the ocean." —Gabriel García Márquez}

\author{
The Autum of the Patriarch
}

Analyses of economic crises from any angle should always be carried out with a solid foot on the ground: this is to say, with a full awareness of the consequences that these crises bring about for governments, corporations, and, no less importantly, human beings, collectively or as individuals. The US Financial Crisis Inquiry Commission did not miss this important focus and pointed out in 2011, already a while ago and just regarding United States:

As this report goes to print, there are more than 26 million Americans who are out of work, cannot find full-time work, or have given up looking for work. About four million families have lost their homes to foreclosure and another four and a half have slipped into the foreclosure process or are serious behind on their mortgage payments. Nearly $\$ 11$ trillion in household wealth has vanished, with retirement accounts and life savings swept away. ... Many people who abided by all the rules now find themselves out or work and uncertain about the future prospects. The collateral damage of this crisis has been real people and real communities. The impacts of this crisis are likely to be felt for a generation...6

The raw numbers of past crises portray a tragedy. Unemployment increases during a period of five years on average, and the unemployment rate goes up about seven percentage points. ${ }^{7}$ Housing prices decline on an average of $35.5 \%$ from peak prices and over six years. Average historical reduction in equity prices is $55.9 \%$ and lasts 3.4 years

Faculty of Laws, University College of London, CLES Working Paper Series 6/2012, 84-95, available at http://www.ucl.ac.uk/cles/research-paper-series/research-papers/cles-6-2012 (visited 15 January 2014).

6 Financial Crisis Inquiry Commission, Conclusions, 27 January 2011, xv, xvi, available at http://fcic-static. law.stanford.edu/cdn_media/fcic-reports/fcic_final_report_conclusions.pdf (visited 14 January 2014). The full report is available at http://www.gpo.gov/fdsys/pkg/GPO-FCIC/pdf/GPO-FCIC.pdf (visited 5 January 2014). The extent of the impact of the financial crisis can be perceived in the following clip of a popular American TV show, Dr. Oz, 'The New Face of Hunger in America', available at http://www.doctoroz.com/episode/new-face-hunger-america. There, it is shown that poverty is no longer concentrated in traditional minorities, but that the majority also significantly suffers the impact of the crisis, something corroborated by IMF research. See Abdul Abiad, Ravi Balakrishnan, Petya Koeva Brooks, Daniel Leigh, and Irina Tytell, 'What's the Damage: Medium-term Output Dynamics after Financial Crises', Working Paper 09/245, at 19, International Monetary Fund, 2009, available at http://www.imf.org/external/pubs/ft/wp/ 2009/wp09245.pdf (visited 14 January 2014).

7 See Carmen M Reinhart and Kenneth S Rogoff, 'The Aftermath of Financial Crises', NBER Working Paper No. 14656, January 2009, 6, available at http://www.nber.org/papers/w14656.pdf?new_window=1 (visited 16 January 2014) [Reinhart and Rogoff, Aftermath]. This article contains evaluations of eighteen financial crises in developed economies. 
on average. Gross domestic product falls $9.3 \%$, and the decline lasts two years on average. ${ }^{8}$ Government debt rises $86 \%$ over the three years after a banking crisis takes place. The explanation for such significant impact is a sharp reduction in tax revenue and significant increases in public spending to fight crises. ${ }^{9}$

This time the output losses of the Great Recession have already significantly exceeded those of recent crises. Output is, on average, $17 \%$ below the pre-crisis pattern after five years: the average of prior crises was $9 \%,{ }^{10}$ and there is evidence that the losses are more lasting. In the past, output returned to its pre-crisis level within five years. This time around, none of the countries that have experienced a banking crisis have returned to the pre-crisis output level. ${ }^{11}$

But there are other costs no less important and unaccounted for in economics: the political costs. Contrary to wars against external enemies, which rally societies around a common goal, economic crises fragment them and bring about severe political instability and civil unrest. ${ }^{12}$

It is then understandable to find that governments and markets seek to avoid all these costs. With the significant stakes at hand, the prediction of economic crises has always been a matter of discussion and analysis. Although, as Krugman states, 'Economies are complicated, ever-changing entities', ${ }^{3}$ there is a body of economic research aimed at identifying indicators of the emergence of economic crisesbanking, debt or currency crises - called 'early warning' literature. The need for early warning models (EWMs) appeared after the 1994 Mexican crisis and gained momentum after the 1997 Asian crisis. ${ }^{14}$ Given the amount of resources to be devoted to this area of research in the years to come, it is expected that important developments will take place and that EWMs will increasingly be used as a policy instrument by States.

\title{
B. Economic Crises and the Progressive Development of EWMs
}

Seules les choses non dénombrées, non enregistrées et aux caractéristiques non déterminables provoquaient des catastrophes redoutables.

\author{
Orhan Pamuk \\ IsTANBUL, SOUVENIRS D'UNE VILLE
}

8 See ibid, at 8 .

9 See ibid, at 10. Bailouts do not seem to constitute a significant element of post-crisis debt burdens. See ibid, at 10 .

10 See Abiad et al., supra note 6, 24.

11 See ibid.

12 The current Great Recession has not been the exception, the Occupy Wall Street movement in USA and the Indignados in Spain being just two examples. On the former movement, see David Graeber, The Democracy Project: a History, a Crisis, a Movement (2013).

13 Paul Krugman, 'How the Case for Austerity Has Crumbled', New York Review of Books, 6 June 2013, 3, available at http://www.nybooks.com/articles/archives/2013/jun/06/how-case-austerity-has-crumbled/ (visited 15 January 2014) [Krugman, How the Case for Austerity Has Crumbled].

14 See Andrew Berg, Eduardo Borensztein, and Catherine Pattillo, 'Assessing Early Warning Systems: How Have They Worked in Practice?', IMF Staff Papers 52(3), 462, 463 (2005), available at http://www.imf. org/External/Pubs/FT/staffp/2005/04/pdf/berg.pdf (visited 15 January 2014). 
It is, then, not surprising that economists have been trying to develop models that identify early signals of emerging crises and prevent their catastrophic losses. The Great Recession has brought attention back to economic research of this character. Telling proof of this new reality is the words of the then IMF Managing Director in the aftermath of the global financial crisis: 'We at the Fund have already begun intensifying our early warning capabilities and will be strengthening our collaboration with others involved in this area. 15

The early warning literature includes models focussed on developed economies, ${ }^{16}$ on developing and emerging economies, ${ }^{17}$ and also on all kinds of economies combined. ${ }^{18}$ In addition, and most recently, EWMs have been designed for single economies. ${ }^{19}$ The models are not designed to attempt to anticipate economic crises of all sorts. ${ }^{20}$ In effect, there are EWMs specifically developed for currency crises, debt and banking crises, ${ }^{21}$ private sector debt crises, or equity market crises. Further, it is important to keep in mind that even EWMs designed to anticipate the same types of crises may differ on the definition of when such a crisis is emerging, ${ }^{22}$ the variables selected, and the countries whose data are included, to mention but a few differences.

There are two main models: the discrete and continuous representation of crises. The discrete representation model is able to send clear signals to policy-makers regarding warning indicators when they have reached a certain threshold. ${ }^{23}$ It is for the modeller to determine such threshold, and he or she must try to balance the risk of making two different kinds of mistakes. A low threshold increases the risk of false alarms, the risk being that of sending a warning for situations in which no serious risk of a crisis exists. The modeller of EWMs must also avoid a high threshold, which

15 Dominique Strauss-Kahn, 'Letter from IMF Managing Director Dominique Strauss-Kahn to the G20 Heads of Governments and Institutions', 9 November 2008, as quoted by Andrew K Rose, Mark M Spiegel, 'Could an early warning system have predicted the crisis?', 3 August 2009, Blog: Vox Researchbased Policy Analysis and Commentary from Leading Economists, available at http://www.voxeu.org/art icle/could-early-warning-system-have-predicted-crisis (visited 12 January 2014).

For a general description of the early warning literature and of its different methodologies, models, and indexes, see Jan Babecký, Tomáš Havránek, Jakub Matějů, Marek Rusnák, Kateřina Šmídková and Bořek Vašíček, Leading Indicators of Crisis Incidence, Evidence from Developed Countries, European Central Bank, Working Paper Series, No. 1486. October 2012, 5-6, available at http://www.ecb.int/pub/pdf/ scpwps/ecbwp1486.pdf (visited 13 January 2014) [Babecký et al.].

16 See ibid, at 8.

17 See Berg et al., supra note 14, 462-502; M Bussière, 'Balance of Payment Crises in Emerging Markets: How Early Were the 'Early' Warning Signals?', 45(12) Applied Economics 1601 (2013) [Bussière, How Early Were the Warning Signals].

18 See Babecký et al., supra note 15, 7.

19 See Ian Christensen and Fuchun Li, A Semiparametric Early Warning Model of Financial Stress Events, Bank of Canada, Working Paper 2013-13, at 1, available at http://www.bankofcanada.ca/wp-content/up loads/2013/05/wp2013-13.pdf (visited 7 January 2014). Models designed for single countries face a challenge: how to rely only on domestic information if the given State's financial system is highly integrated within international markets. See ibid, at 6.

20 The mathematics of the models is not included here. It can be consulted in the secondary sources cited in this article.

21 See Berg et al., supra note 14, 467.

22 For instance, policy-makers and private actors, such as private financial institutions, may differ and have differed in their EWMs regarding the definition of when there is a currency crisis. See ibid. See Babecký et al., supra note 15, 6-7. 
increases the risk of missing crises, those the EWM is not able to identify. ${ }^{24,25}$ EWM design may well incorporate an inclination to avoid one mistake more than the other, or to give to the model equal weight. ${ }^{26}$

As to the continuous EWMs, Babecký et al. state:

continuous indicators of crisis have been proposed... that allow the EWM to explain the actual scale of real costs or nominal movements without the need to decide whether the scale is sufficiently high to produce a 'yes' value. Another advantage is that continuous indicators do not suffer from a lack of variation of the dependent variable when too few crisis events are observed in the data sample.... The disadvantage of this approach lies in its limited capacity to send straightforward ('yes/no') signals to policy makers regarding the probability of crises. ${ }^{27}$

Regardless of the type of EWM, it is important to determine what the appropriate indicators are for a model to truly render warnings of a potential crisis meaningful, a topic that will be addressed below. ${ }^{28}$ These indicators are not fixed, but evolve and have been increased, ${ }^{29}$ as a result of past unpredicted crises with new dimensions and causes.

24 See Matthieu Bussiere and Marcel Frarzcher, 'Towards a New Early Warning System of Financial Crisis, 25 Journal of International Money and Finance 953, 957 (2006).

The risk of failing to take into consideration certain information that later turns out to be important is by no means limited to EWM literature. Any econometric exercise faces a similar risk. Carmen M Reinhart and Kenneth S Rogoff, two very influential American scholars, have just recently experienced it. By not taking into account certain variables, an important conclusion they arrive at-according to which economic growth was to stagnate in an economy once its government debt-to-GDP ratio was higher than $90 \%$, which had a significant influence on and justified US and European austerity policies - proved not to be accurate, as the authors themselves acknowledged. See Carmen M Reinhart and Kenneth S Rogoff, 'Growth in a Time of Debt', National Bureau of Economic Research, Working Paper 15639, January 2010, available at http://www.nber.org/papers/w15639.pdf (visited 7 January 2014). The challenging paper was Thomas Herndon, Michael Ash and Robert Pollin, 'Does High Public Debt Consistently Stifle Economic Growth? A Critique of Reinhart and Rogoff, University of Massachusetts Amherst, Working Papers Series. No 322, 15 April 2013, available at http://www.peri.umass.edu/fileadmin/pdf/working papers/working_papers_301-350/WP322.pdf (visited 6 January 2014). According to Krugman, 'Reinhart-Rogoff may have had more immediate influence on public debate than any previous paper in the history of economics'. Krugman, How the Case for Austerity Has Crumbled, supra note 13, 1, available at http://www.nybooks.com/articles/archives/2013/jun/06/how-case-austerity-has-crumbled/. See also Lawrence Summers, 'Lessons can be learned from Reinhart-Rogoff error', Washington Post, 5 May 2013, available at http://www.washingtonpost.com/opinions/lessons-can-be-learned-from-reinhart-rogofferror/2013/05/05/6ea6aa72-b43f-11e2-bbf2-a6f9e9d79e19_story.html (visited 6 January 2014).

The notion of false alarms must be qualified. It should not include events in which policy measures are taken in response to the warning and no crisis ensues. See Berg et al., supra note 14, 489.

26 See ibid, at 475-76.

27 Babecký et al., supra note $15,7$.

28 See ibid, at 17 . The variables may well vary depending on the type of crises that the given EWM deals with.

29 For instance, the expansion of international financial markets is a new element with EWMs. See Andrew Berg and Catherine Pattillo, 'The Challenges of Predicting Economic Crises', IMF Economic Issues No 22 (2000), available at http://www.imf.org/external/pubs/ft/issues/issues22/index.htm\#3 (visited 10 January 2014). 
Babecký et al. identified, on the basis of 30 potential early indicators in the European Union and OECD over the last 40 years, some key warning factors. They were, first, excessively rapid growth in domestic credit to the private sector with a four-year $\mathrm{lag}^{30}$; and second, a high ratio of debt-to-gross domestic product (GDP), which may be associated with a significant reduction in international trade, exclusion from international financial markets, and higher borrowing costs. ${ }^{31}$ Other, although late, early warning indicators are government debt, current account deficits, foreign direct investment, and fall in house prices and share prices. These are risk factors that deserve to be monitored. ${ }^{32}$

Bussière has also recently further developed his previous EWM on the basis of a prediction of vulnerability of emerging countries to currency crises within a time window of twelve months. ${ }^{33} \mathrm{He}$ has found that the following variables predict currency crises: the ratio of short term debt/international reserves, the over-appreciation of the nominal effective exchange rate vis-à-vis its trend, and contagion from other economies. $^{34}$

A very important point is the inclusion of political variables within EWMs, as a necessary complement to improve their performance. Bussière and Mulder have done so. ${ }^{35}$ They have incorporated variables such as the occurrence of elections and the stability of governments in one of their models. ${ }^{36}$

Although EWMs cannot anticipate the exact date on which a crisis will hit a country or a set of countries, they can offer a time window. ${ }^{37}$ In effect, recent economic research within the EWM literature has developed models aimed at identifying the time lag between a warning of a potential crisis and the potential timing of its occurrence. $^{38}$ Babecký et al. regard that the lag of the early warnings must be a minimum of one year so that policy-makers can still be able to take preventive measures. ${ }^{39}$

Further, to be useful for policy-makers, the models must rely on data related to the relevant indicators from various economies for long periods of time, which may

30 See Babecký et al., supra note 15, 21.

31 See ibid.

32 See ibid, at 22.

33 The time window is determined through expert judgment, and most EWMs have a one- to two-year window. See ibid, at 10.

34 See Bussière, How Early Were the Warning Signals, supra note 17, 1618.

35 See Mattieu Bussière and Christian Mulder, 'Political Instability and Economic Vulnerability', 5 International Journal of Finance and Economics 309 (2000).

36 See Matthieu Bussière and Christian Mulder, 'In Defense of Early Warning Signals', December 2010, at 7 (unpublished paper), available at http://www.researchgate.net/publication/228532957_In_Defense_of_ Early_Warning_Signals (visited 8 January 2014) [Bussière and Mulder, Early Warning Signals]. Bussière also mentions in a more recent article that some institutional features that may have a bearing on crises may nonetheless be difficult to incorporate within EWMs, such as the operation of the judicial system, contract enforcement and the rule of law. See Bussière, How Early Were the Warning Signals, supra note $17,1606$.

It is worth mentioning that country risk scores include political economy variables. See in this regard, Andrew K Rose and Mark M Spiegel, 'Cross-Country Causes and Consequences of the Crisis: An Update', 55 European Economic Review 309 311.n.5. (2011) [Rose and Spiegel, Causes and Consequences of the Crisis: An Update].

37 See Bussière, How Early Were the Warning Signals, supra note 17, 1603.

38 See Babecký et al., supra note $15,13$.

39 See ibid. 
sometimes be a challenge. ${ }^{40}$ For instance, indicators that may be identified after a crisis as being useful to predict others in the future-such as liquidity and leverage ratios - may be difficult to incorporate within new models, because there are no data on them for some countries, ${ }^{41}$ the data are available but for a limited period of time, ${ }^{42}$ or the data are available but are not reliable. ${ }^{43}$ In any case, no EWM can incorporate all variables for each country. ${ }^{44}$

Also, the set of countries included within the data should share some features for the given model to identify common causes of crises. ${ }^{45}$ It has also been suggested that EWMs include two types of variables, fundamentals ${ }^{46}$ and vulnerabilities, ${ }^{47}$ for they complement each other. ${ }^{48}$

The models are tested in two ways, say Berg and Cantillo:

on the data and time period for which they were designed (called in-sample performance), and on data or a time period for which they were not specifically designed (called out-of-sample performance). Clearly for a model to be useful it would have to provide informative signals out-of-sample, that is, beyond the time period for which the model itself was estimated. ${ }^{49}$

In addition, in-sample models performed better than out-of-sample ones, since the latter may not have included variables that later turn out to be relevant to the emergence of a crisis, or they did not receive sufficient weight within the model. ${ }^{50} \mathrm{Such}$ was the case with the models prior to the Asian crisis. However, it is the out-ofsample tests of EWMs that are useful to policy-makers, since it is their result that may trigger preventive actions or measures. ${ }^{51}$

40 See ibid, at 8.

41 For instance, Berg and Pattillo point out that the short-term foreign debt of the private sector is not available for many countries. See Berg and Pattillo, supra note 29.

42 See Babecký et al., supra note $15,8$.

43 This is the case regarding information on lending booms, in which data on the level of bad loans may not be reliable for under-reporting reasons. See Bussière, How Early Were the Warning Signals, supra note 17, 1604.

44 See ibid, at 1602.

45 See ibid, at 1604. Care must be taken also regarding the comparability of risks in multi-country models. As the Asian crisis revealed, a currency crisis may occur in many countries at the same time but for different reasons. The said crisis affected some Asian countries due to risks associated with the banking sector, while the crisis spread to Latin American countries owing to their large fiscal deficits. How to capture these differences in models that identify trends is a challenge.

46 For instance, the current account balance, level of exchange rate, credit growth, and fiscal balance. See Berg and Pattillo, supra note 29.

47 For instance, EWMs for currency crises include vulnerability variables aimed at determining the likelihood of successful defence of a currency in the event of an attack. To this end, the model may include a variable that determines a ratio between the level of international reserves and foreign and domestic short-term liabilities. The lower the first and the higher the second, the higher the vulnerability of a domestic currency to an attack. See ibid.

48 See ibid.

49 See ibid.

50 See ibid.

51 An EWM developed by Bussière applied out-of-sample to the 2007 crisis was able to predict a currency crisis for eight countries, and other eight countries would not suffer a crisis. However, the EWM gave five 
Finally, it is important to keep in mind that EWMs cannot be confounded with absolute future prediction. As Babecký pointed out to the present author:

predicting the exact timing of the crises is a very challenging issue. The concept of the early warning models should be rather perceived from a bit different viewpoint: the fact that model issues a warning signal does not automatically mean that there is a crisis coming. It is just a 'blinking indicator', a call for attention. ${ }^{52}$

Since antiquity, and as the ancient Arab poet once said centuries ago, 'I know what is happening today and what happened yesterday, but I cannot tell what tomorrow will bring. ${ }^{53}$ Although prospective analyses are part of today's world, they have constraints that must always be kept in mind. ${ }^{54}$

\section{Early warning models vis-à-vis other instruments developed to anticipate economic crises}

An analysis of EWMs is not complete without looking at the performance of other tools that governments, international financial institutions, and markets use to attempt to anticipate economic crises of any sort, such as pure guess research and non-model-based forecasts such as agency ratings and private analysts rating currency risks. ${ }^{55}$

EWMs have been compared to non-model methods. Berg, Borensztein, and Pattillo of the IMF did so in 2005 after the Asian currency crisis. According to these authors, the EWMs designed prior to this event, although not excessively accurate, did identify the vulnerability of some countries that were hit by the crisis, ${ }^{56}$ although not all of them ended up being affected by it. ${ }^{57}$

By contrast, sovereign spreads, a non-model-based indicator of currency risk, did a poor job as predictor of the countries affected by the Asian crisis. ${ }^{58}$ The same can be said of sovereign ratings by agencies such as Standard \& Poor's and Moody's. The ranking of the 10 most affected countries was much better than that of the 10 leastaffected countries, ${ }^{59}$ precisely the opposite from what could be expected of a tool

false alarms and missed crises in four countries. See Bussière, How Early Were the Warning Signals, supra note 17,1618 .

52 E-mail communication. On file with author.

53 FA al-Bustani et al., al-Majani al-haditha, Vol. I, 1946, at 103.

54 Prospective analysis is a challenge not only for EWMs but for any econometric analysis. As Lawrence argues, 'The extrapolation from past experience to future outlook is always deeply problematic and needs to be done with great care'. See Summers, supra note 24.

55 Public and private models to anticipate economic crises differ in their design. The former are more longterm oriented in order for policy-makers to adopt measures to prevent the calamity, whereas the latter have a more short-term orientation. However, private sector models are important, given that they are widely circulated among investors, and they rely on them for their decisions. See Berg et al., supra note 14, 463-46.

56 See ibid, at 469.

57 The applied EWM identified Brazil and the Philippines as vulnerable countries, although they were not hit hard by the Asian crisis, according to Berg et al. See Berg et al., supra note 14, 469.

58 See ibid.

59 See ibid, at 471. 
aimed at anticipating costly economic events. A third non-model-based predictor, surveys of currency market analysis, includes quantitative and qualitative variablesfrom macroeconomic factors to others referring to the quality of economic and political decision-making - for several countries. The surveys rendered similar disappointing results. They gave favourable assessments to the countries more hit by the crisis before it took place. And in contrast, countries with higher risk evaluations in the surveys ended up being less likely to have a crisis during the years 1997-98. ${ }^{60}$

In concluding, Berg, Borensztein, and Pattillo state:

[T] here is little evidence that "market views," or analysts' views, as expressed in spreads, ratings, and surveys, are reliable crisis predictors, important as they may be in determining market access....

The results of this round of EWS testing were sufficiently promising to suggest the continued implementation of these models on an ongoing basis, along with further research and development. ${ }^{61}$

\section{Criticism of early warning models}

Not everybody agrees on the effectiveness of EWMs, ${ }^{62}$ in part because crises are hard to anticipate, due to the complex mix of economic, political, and psychological factors that trigger them. ${ }^{63}$ Some scholars think, like Jorge Luis Borges in Fictions, that 'reality does not usually coincide with predictions'.

EWMs have been questioned on a set of grounds. The first is what is called the impossibility theorem. According to the theorem, crises cannot be predicted. If they were, policy-makers would take actions and prevent them, which would mean that the model could no longer be accurate. ${ }^{64}$

The second criticism aimed at EWMs lies on the other side of the spectrum. The criticism is called the self-fulfilling prophecy. EWMs are dangerous. That is, in the aftermath of a warning of a crisis, market participants or policy-makers may react in a way that triggers the very crisis anticipated. For instance, in the face of a currency crisis, market participants will sell the given currency and bring about the crisis. ${ }^{65}$

The European Systemic Risk Board has recognized the existence of this worrisome dimension of EWMs and suggested caution in the handling of the conclusions that these models may yield:

The issues potentially addressed in the warnings and recommendations will be extremely sensitive and we must be careful about adverse effects, such as the warnings turning into self-fulfilling prophecies by frightening financial markets.

60 See ibid.

61 See ibid.

62 See Rose and Spiegel, Causes and Consequences of the Crisis: An Update, supra note 36.

63 See Berg and Pattillo, supra note 29.

64 See Bussière and Mulder, Early Warning Signals, supra note 36, 6.

65 See ibid, at 3. It is argued that the Mexican crisis was partly the cause of such self-fulfilling prophecies. Certainly, other factors contributed to this particular crisis, such as a large current account deficit prompted by an over-valuated Mexican peso. See Berg and Pattillo, supra note 29. 
The decision whether or not to publish will, therefore, require a case-by-case decision after a careful assessment of the potential consequence. ${ }^{66}$

However, among the main critics of EWMs are Rose and Spiegel, according to whom:

Despite the fact that we use a wide number of possible causes in a flexible statistical framework, we are unable to link most of the commonly-cited causes of the crisis to its incidence across countries. This negative finding in the crosssection makes us sceptical of the accuracy of "early warning" systems of potential crises, which must also predict their timing. ${ }^{67}$

This was a statement made in 2009, when the Great Recession was just unfolding. However, Rose and Spiegel updated this research in 2012, incorporating not only data generated during the crisis - up to 2010 - but also the new literature on EWMs. ${ }^{68}$ These authors used a non-structural Multiple Indicator Multiple Cause (MIMIC) model of crises and examined seven variables of crises for 107 countries: GDP growth, underlying growth trend, output gap, consumption growth, and a combination of four variables: multilateral exchange rate, real GDP, national stock market, and country risk ratings. ${ }^{69}$ Rose and Spiegel then individually assessed each of the causes of the Great Recession that had been identified by the literature. ${ }^{70}$ They confirmed some causes of crises across countries, such as pre-crisis current account deficits, more liberal market regulation, run-up in real housing prices, and short-term external debt. ${ }^{71}$ However, the authors did not find such strong results when all of the causes were considered simultaneously.

The above-mentioned authors found that current account deficits and credit market regulations strongly explained the 2008-09 crises in several countries, but both

66 See on-line discussion, available at http://europa.eu/rapid/pressReleasesAction.do? reference=MEMO/ $09 / 405 \&$ format $=$ HTML\&aged $=0$ \&language $=\mathrm{EN} \&$ guiLanguage $=$ fr. As quoted by Bussière and Mulder, Early Warning Signals, supra note 36, 3.

67 Andrew K Rose and Mark Spiegel, Cross-Country Causes and Consequences of the 2008 Crisis: Early Warning, Italian Ministry of Economy and Finance, Working Papers No 6, September 2009, at 3, available at http://www.dt.mef.gov.it/opencms/opencms/handle404?exporturi=/export/sites/sitodt/modules/documenti_it/analisi_progammazione/working_papers/Working_Paper_FINALE_2_pdf\&\%5D (visited 8 January 2014).

68 See Rose and Spiegel, Causes and Consequences of the Crisis: An Update, supra note 36, 310. As to new developments, these authors highlight the following:

literature has since sprung up which diverges from our methodology in four respects: (a) the measure of crisis intensity (the dependent variable); (b) the potential causes of the crisis (the covariates); (c) the estimation procedure used to link potential causes and consequences of the crisis; and (d) the sample of countries under consideration. In order to see whether our results are incompatible with those of others, we now follow more closely the steps in the literature.

See Rose and Spiegel, Causes and Consequences of the Crisis: An Update, supra note 36, 312. 
variables were not relevant for previous crises, such as that of $2001-02 .^{72}$ On this basis, Rose and Spiegel concluded again:

$[\mathrm{T}]$ he results... are sobering for those who believe in the viability of such cross-country early warning systems.

It is natural for economists to generalize from experiences of a few particularly salient countries to make generalizations, though it is often inappropriate. Our poor regression results are simply telling us that the pre-conditions for the crisis in the United States (or Iceland, or Latvia, etc.) often do not describe other countries particularly well. Credit growth was high before 2007 in Australia, Canada, and South Africa, yet these countries seemed to have weathered the crisis well. Real housing prices actually fell well before the crisis in Japan, Germany and Portugal, yet these countries were hard hit. Since it is difficult to understand the cross-country incidence of the Great Recession even in retrospect, we are dubious about the potential for comparable "early warning" forecasting model going forward. ${ }^{73}$

\section{Responses to criticisms of early warning models}

However, EWM scholars have responded to some of these criticisms. Bussière and Mulder posit that to ensure the relevance of EWMs and avoid self-fulfilling prophecies, it is necessary to prevent early warnings from being made public. ${ }^{74}$

These authors make a relevant point regarding the importance of EWMs. Even with their limitations, they are a good substitute for judgment-based assessments, because the former offers indications of economic vulnerabilities. ${ }^{75}$ On the other hand, while these authors recognize that the assessment of potential crises needs also to incorporate other criteria, such as information from market participants or market sentiment, ${ }^{76}$ EWMs may serve to narrow the possibility of crisis denial in order to avoid political costs. $^{77}$

In addition, EWMs may render results that are not biased by recent and not-so-recent events or prior successful realities, which may cloud more contemporary judgments urging for preventive action. This was the case with the operation of EWMs in Korea before the Asian crisis. The models rendered vulnerability warnings, but the warnings were not heard because of the overall perception of the Korean success story and the market trust in it. ${ }^{78}$

See Bussière and Mulder, Early Warning Signals, supra note 36, 7.

See ibid. This has been the case with the first generations of EWMs. They are useful to identify what countries are more vulnerable at times of international financial turmoil. See Berg and Pattillo, supra note 29.

76 The inclusion of this information within EWMs is challenging, because it is not easy to measure, on one hand, and on the other, it can provide policy-makers with a warning only once the crisis is on the verge of erupting. See ibid.

77 See Bussière and Mulder, Early Warning Signals, supra note 36, 8.

78 See Berg et al., supra note 14, 491. 
EWMs are in the process of evolution, and all past crises have led to improvements and to identification of new variables not included before. ${ }^{79}$ The fact that they may sometimes miss crises or send false alarms should not lead us to discard EWMs. ${ }^{80}$ Bussière and Mulder suggest that these events may lead to improvements to EWMs in the future. Missed crises give policy-makers and researchers the opportunity to take into account new variables that were not considered by prior models and to improve them. ${ }^{81}$ For instance, risk contagion was not a variable in many $\mathrm{EWMs}^{82}$ and was at the root of the failure of some models to properly anticipate the Great Recession in some countries. ${ }^{83}$ In addition, the existence of false alarms means that there are positive variables, not included within the EWMs, that may help to avoid a given crisis, which, if taken into consideration within EWMs in the future, might lead to their refinement. ${ }^{84}$

In the end, it seems that the right approach to decision-making is to combine EWMs with non-model-based predictors in order to make decisions regarding crisis prevention. The solution may not be as easy as it looks, since the latter have proved to not be reliable as crisis predictors in the not-so-distant past, according to

79 To mention but an example, the first generation of EWMs developed during the 1970s, among others, by Paul Krugman did not anticipate the 1990s crises. After them, it was clear that government budget balance and, in particular, a higher surplus increased the risk of a crisis, even if this looked paradoxical, and had to be incorporated within the next generation of EWMs. As to the first generation of EWMs, see Paul Krugman, 'A Model of Balance-of Payments Crises', 11 Journal of Money, Credit and Banking 311 (1979). As to the evolution of EWMs regarding the particular topic highlighted in this footnote, see Bussière, How Early Were the Warning Signals, supra note 17, 1608.

80 It is important to highlight that, given that EWMs collect data from different countries, their ex post general application to a set of countries may lead one to conclude that they accurately predicted a crisis in relation to some countries, missed others, and also produced false alarms regarding other countries. For instance, the ex post application of the Bussière and Mulder's model designed in the 1990s to the 2008 crisis indicated significant vulnerabilities for some countries, failed to predict vulnerabilities for Malaysia, and led to a wrong warning for Hungary. See Bussière and Mulder, Early Warning Signals, supra note 36,12 .

81 See ibid, at 8.

82 However, this is not to say that contagion was never regarded as a risk, since prior to the Great Recession, currency crises usually spread across countries. See Bussière, How Early Were the Warning Signals, supra note 17,1601 . However, Bussière has also shown that contagion can also create positive outcomes, since a currency crisis in one country may bring about a flow of investment to other emerging economies, as was the case after the 1994 Mexican crisis, when investors moved to the emerging economies in Asia. See ibid, at 1608.

83 See Bussière and Mulder, Early Warning Signals, supra note 36, 13. The contagion took place, first, regarding the sub-prime crisis from USA to Europe, and, second, the expansion of the sovereign crisis within European Union economies. As to the former, see Giovanni Lombardo and Luca Dedola, Financial Frictions, Financial Integration and the International Propagation of Schocks, European Central Bank, ECB Research Bulletin. No 14, Autumn 2011, 5, and as to the latter, see Giovanni Amisano and Oreste Tristani, The Euro Area Sovereign Crisis: Monitoring Spillovers and Contagion. European Central Bank, ECB Research Bulletin. No 14, Autumn 2011, at 2, available at http://www.ecb.int/pub/pdf/other/ researchbulletin 14en.pdf (visited 8 January 2014). It may be worth noting that definitions of the term 'contagion' can vary. See Amisano and Tristani, supra note 83, 1, and Steven B Kamin and Laurie Pounder De Marco, How Did a Domestic Housing Slump Turn into a Global Financial Crisis?, Board of Governors of the Federal Reserve System, International Finance Discussion Papers. Number 994, January 2010, available at http://www.federalreserve.gov/pubs/ifdp/2010/994/default.htm (visited 15 January 2014). See Bussière and Mulder, Early Warning Signals, supra note 36, 8. 
the IMF. ${ }^{85}$ But on the other hand, the current Great Recession is rooted in an excessive reliance on mathematical models, with little judgment, by financial institutions, ${ }^{86}$ so the combination of economics and judgment seems to be the best one to be carried out by governments regarding the assessment of crisis imminence. Bussière and Fratzscher synthesize well the role EWMs should play in policy-making:

It should be stressed that [Early Warning System] models cannot replace the sound judgment of the policy maker to guide policy, but they can play an important complementary role as a neutral and objective measure of vulnerability. $^{87}$

With the amount of additional information brought about by the current financial crisis and with the substantial research that is focussing on EWMs in recent years, it may be safe to say that important improvements to the theoretical models can be expected. EWMs are here to stay.

This article, however, does not claim that EWMs will always be used as a policymaking tool. Even in the face of clear warnings, governments have strong incentives to avoid the political and economic costs of recognizing the existence of an upcoming economic crisis. Crisis denial is not an uncommon reality; on the contrary, it is regarded as an initial stage in the development of economic calamities. ${ }^{88}$ Instead, this article deals mainly with the issue of crises that are sought to be prevented on the basis of the use of EWMs. ${ }^{89}$

\section{EARLY WARNING MODELS AND NECESSITY IN INTERNATIONAL LAW}

As EWMs develop further as a response to the Great Recession, it would not be surprising to see that their use as a policy-making tool by governments increases. How do EWMs interact with international investment law?

The first, and surely most important, interaction is when a State, relying on signals from EWMs, adopts measures that, while violating an international obligation owed to an investor, successfully prevent a crisis that is likely to unfold. As a result,

85 See Berg et al., supra note 14, 491.

86 See Financial Crisis Inquiry Commission, supra note 6, xix.

87 Bussière and Fratzscher, supra note 24, 970.

88 See Edwin M Truman, Policy Responses to the Global Financial Crisis, Peterson Institute for International Economics, Remarks presented at the Ninth Annual International Seminar on 'Policy Challenges for the Financial Sector Emerging from the Crisis: Building a Stronger International Financial System', Board of Governors of the Federal Reserve System, World Bank, and International Monetary Fund, 3 June 2009, available at http://piie.com/publications/papers/paper.cfm?ResearchID=1225 (visited 12 January 2014). See also Anna Gelpern, 'Financial Crisis Containment', 42 Connecticut Law Review 493, 506-13 (2009).

89 It can also be claimed that the use of EWMs may not occur with ease, since policy-makers may lack the economic expertise to act upon these models. This claim should be viewed with care. Although it is undeniable that economic policy-making is embedded within domestic and even international politics and also driven by political concerns, large bureaucracies, not uncommon in countries of all sorts and sizes, are familiar with economic analyses, even if those presiding over them lack a strong background in economics. It is hardly the case in modern government that the scope of public action is set by the intellectual acumen of the officials vested with the power to enact regulations or make decisions in the economic realm. 
the host State avoids the losses associated with the averted crisis, but it faces the investor's claim of violation.

The host State may seek to justify its measure on the basis of non-precluded measures clause provided for in a bilateral investment treaty or to excuse it on the basis of the customary rule of necessity embodied in Article 25 of the International Law Commission Articles on State Responsibility, if the given BIT does not provide for such a clause. ${ }^{90}$ According to this provision:

1. Necessity may not be invoked by a State as a ground for precluding the wrongfulness of an act not in conformity with an international obligation of that State unless the act:

a. is the only means for the State to safeguard an essential interest against a grave and imminent peril; and

b. does not seriously impair an essential interest of the State or State towards which the obligation exists, or of the international community as a whole.

2. In any case, necessity may not be invoked by a State as a ground for precluding wrongfulness if:

a. the international obligation in question precludes the possibility of invoking necessity; or

b. the State has contributed to the situation of necessity. ${ }^{91}$

Before the 2001 Argentine crisis, the international law of necessity was very thin, although the 1990s had seen a groundbreaking judgment by the International Court of Justice (ICJ) in the Case Concerning the Gabcikovo-Nagymaros Project (Hungary/ Slovakia). ${ }^{92}$ Today, the international law of necessity is a very dynamic area of public

90 See Award, In the Matter of an UNCITRAL Arbitration, National Grid P.L.C. v Argentine Republic, 9 180, 3 November 2008. g 256 [National Grid Award], available at http://ita.law.uvic.ca/documents/ NGvArgentina.pdf (visited 10 January 2014).

91 James Crawford, The International Law Commission's Articles on State Responsibility. Introduction, Text and Commentaries 178 (2002) [hereinafter ILC's Commentaries].

92 See International Court of Justice, Case Concerning The Gabcikovo-Nagymaros Project (Hungary/ Slovakia), Judgment of 25 September 1997, I.C.J. Reports 1997, 7 [Gabcikovo-Nagymaros], available at http://www.icj-cij.org/docket/index.php?p1 $=3 \& \mathrm{p} 2=3 \& \mathrm{k}=8 \mathrm{~d} \&$ case $=92 \& \operatorname{code}=\mathrm{hs} \& \mathrm{p} 3=4$ (visited 10 January 2014).

There, the Court held that the above-mentioned provision had the status of customary international law; that the concept had to be interpreted very narrowly, since it served to excuse wrongful acts under international law; and that the requirements must be satisfied cumulatively by the State invoking necessity. See ibid, $\mathbf{9}$ 51. International arbitration tribunals have supported this conclusion, see, for instance, International Centre for Settlement of Investment Disputes, Impregilo S.p.A v. Argentine Republic, Award, 21 June 2011. ICSID Case No. ARB/07/17. gg 344, available at https://icsid.worldbank.org/ICSID/ FrontServlet?request Type $=$ CasesRH\&actionVal $=$ showDoc $\&$ docId $=$ DC2171_En $\&$ caseId $=$ C109 (visited 8 January 2014). See Total S.A v Argentine Republic, Decision on Liability, ICSID Case No ARB/ 04/1, 27 December 2010, g 221 [Total Decision on Liability], available at http://italaw.com/documents/ TotalvArgentina_DecisionOnLiabilty.pdf (visited 4 January 2014).

For a complete assessment of the requirements in light of recent case law, see Andrea K Bjorklund, 'Emergency Exceptions: State of Necessity and Force Majeure', in Peter Muchlinski, Federico Ortino and Christoph Schreuer (eds), Oxford Handbook of International Investment Law, (Oxford: Oxford University Press, 2008) 459, 474-88 [Bjorklund, Emergency Exceptions]. 
international law and international investment law due to the significant number of international decisions and to the booming scholarship they have engendered. ${ }^{93}$

Although BIT non-precluded measures clauses and Article 25 are separate provisions and the former cannot be interpreted in light of the latter, ${ }^{94}$ there are common elements. An important one for the purpose of this article is the kind of crises that may fall under them. The case law is consistent in including economic crises as the

93 See, among many, Alberto Alvarez-Jiménez, 'New Approaches to the State of Necessity in Customary International Law: Insights from WTO Law and Foreign Investment Law', 19 American Review of International Arbitration 463 (2008); Alberto Alvarez-Jiménez, 'Foreign Investment Protection and Regulatory Failures as States' Contribution to the State of Necessity under Customary International Law: A New Approach Based on the Complexity of Argentina's 2001 Crisis', 27 Journal of International Arbitration 141 (2010); Alberto Alvarez-Jimenez, 'The Interpretation of Necessity Clauses in Bilateral Investment Treaties After The Recent ICSID Annulment Decisions', 3 Yearbook on International Investment Law and Policy 411 (2011) [Alvarez-Jimenez, The Interpretation of Necessity Clauses in BITs]; William W Burke-White and Andreas von Staden, 'Investment Protection in Extraordinary Times: The Interpretation and Application of Non-Precluded Measures Provisions in Bilateral Treaties', 48 Virginia Journal of International Law 307 (2007-2008); Jacques Werner, 'Revisiting the Necessity Concept', 10 Journal of World Investment and Trade 549 (2009); José Manuel Cortés Martín, 'El Estado de Necesidad en Materia Económica y Financiera', XXV Anuario Espanol de Derecho Internacional 119 (2009); Jurgen Kurtz, 'Adjudging the Exceptional at International Investment Law: Security, Public Order and Financial Crisis', 59 International and Comparative Law Quarterly 325 (2010); Bjorklund, Emergency Exceptions, supra note 92; Andrea K Bjorklund, 'Economic Security Defenses in International Investment Law', 1 Yearbook on International Investment Law \& Policy 479 (2009); Michael Waibel, 'Two Worlds of Necessity in ICSID Arbitration: CMS and LG\&E', 20 Leiden Journal of International Law 637 (2007); José E Alvarez and Kathryn Khamsi, 'The Argentine Crisis and Foreign Investors. A Glimpse into the Heart of the Investment Regime', 1 Yearbook on International Investment Law and Policy 379 (2008/2009); José E Alvarez and Tegan Brink, 'Revisiting the Necessity Defense: Continental Casualty v. Argentina', 3 Yearbook on International Investment Law and Policy 319 (2010/ 2011); Tarcisio Gazzini, 'Necessity in International Investment Law: Some Critical Remarks on CMS v Argentina', 26 Journal of Energy \& Natural Resources Law 450 (2008); Théodore Christakis, 'Quel Remede A L'Eclatement de la Jurisprudence CIRDI sur les Investissements en Argentine? La Decision du Committe Ad Hoc Dans L’Affaire CMC c. Argentina', CXI Revue General du Droit International Public 879 (2007); Campbell McLachlan, 'Investment Treaties and General International Law', 57 International and Comparative Law Quarterly 361 (2008); Stephan W Schill, 'International Investment Law and the Host State's Power to Handle Economic Crises. Comment on the ICSID Decision in LG $\jmath^{\prime} E$ v. Argentina', 24 Journal of International Arbitration 265 (2007); August Reinisch, 'Necessity in International Investment Arbitration-An Unnecessary Split of Opinions in Recent ICSID Cases? Comments on CMS v. Argentina and LG ${ }^{\prime} E$ v. Argentina', 8 Journal of World Investment \& Trade 191 (2007); Emmanuel Gaillard, 'Chronique des Sentences Arbitrales. Centre International pour le Règlement des Différends Relatifs aux Investissements', 134 Journal du Droit International 335 (2007); Antoine Martin, 'Investment Disputes after Argentina’s Economic Crisis: Interpreting BIT Non-precluded Measures and the Doctrine of Necessity under Customary International Law', 29 Journal of International Arbitration 49 (2012).

94 See Ad Hoc Committee, CMS Gas Transmission Company v Argentine Republic, Decision of the Ad Hoc Committee on the Application for Annulment of the Argentine Republic, ICSID Case No ARB/01/8 (25 September 2007), g 131 [CMS Decision on Annulment], available at http://icsid.worldbank.org/ICSID/ FrontServlet?requestType $=$ CasesRH\&actionVal $=$ showDoc\&docId $=$ DC505_En\&caseId $=C 4 \quad$ (visited 13 January 2014); Ad Hoc Committee, Sempra Energy International v Argentine Republic, Decision on the Argentine Republic's Application for Annulment of the Award, ICSID Case No ARB/02/16 (29 June 2010) [hereinafter Sempra Decision on Annulment], available at http://icsid.worldbank.org/ICSID/ FrontServlet?request $\mathrm{Type}=$ SearchRH\&actionVal $=$ SearchSite $\&$ SearchItem $=$ sempra (visited 10 January 2014); Award, In the Proceedings between Continental Casualty Company v. The Argentine Republic, 27 August 2008, 9167 [Continental Award], available at http://www.investmenttreatynews.org/documents/ p/24.aspx (visited 12 January 2014). 
type of event that may justify or excuse a violation of a treaty provision. ${ }^{95}$ In CIL, necessity can be invoked regarding the protection of a broad set of interests that may qualify as being essential. Relying on the work of the International Law Commission (ILC), the ICJ held in Gabcikovo-Nagymaros that essential interests were not only just those associated with the existence of States. ${ }^{96}$ Second, the nature of the peril that may justify the use of this rule of customary international law is strictly defined. Article 25 speaks of 'grave and imminent peril', and the ICJ declared in the foregoing judgment that this kind of peril denoted a sense of immediacy and proximity. ${ }^{97}$ This is not to say, though, that grave risks that are certain and will inevitably take place in the long run do not qualify as a peril that may trigger the declaration of the state of necessity. The ICJ explicitly expressed that perils of this character could also be regarded as imminent. ${ }^{98}$ The threshold is quite high, since the ICJ has stated that grave risks that are only probable cannot serve as a basis for the declaration of the state of necessity. ${ }^{99}$

As will be seen in more detail below, States can use EWMs to justify the adoption of measures aimed at preventing the occurrence of a severe crisis that EWMs have detected. Or in other words, the question is whether States can rely on EWMs to demonstrate the existence of the requirement of a severe risk over an essential security interest under BIT non-precluded measures clauses, or the imminence of a grave peril over an essential interest under the customary rule of Article 25 of the ILC's Articles. Before delving into this topic, this article will address whether the existence of a lack of consensus or a majority view on the usefulness of EWMs would prevent their use in the interpretation and application of BIT non-precluded measures clauses and the customary rule.

\section{A. Majoritarian acceptance of or consensus on the usefulness of EWMs: not a sine qua non requirement for their use in the interpretation of international law}

Quite important regarding the use of EWMs is whether the existence of a majority on their usefulness is necessary for the models to be relevant in the interpretation of

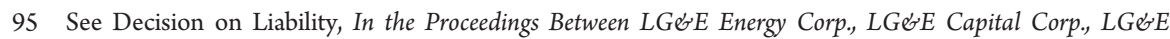
International Inc. and Argentine Republic, g 238. ICSID Case No ARB/92/1 (3 October 2006) [LG\&E Decision on Liability], available at http://icsid.worldbank.org/ICSID/FrontServlet?requestType=Cases RH\&actionVal=showDoc\&docId=DC627_En\&caseId=C208 (visited 13 January 2014); Continental Award, supra note 94, 9 פ 175, 178.

96 See Gabcikovo-Nagymaros, supra note 92, 9 53. For the origin of necessity, see Roman Boed, 'State of Necessity as a Justification for International Wrongful Conduct', 3 Yale Human Rights and Development Law Journal 1, 4 (2000).

97 See Gabcikovo-Nagymaros, supra note 92, פ 54.

98 See ibid.

99 See ibid. Imminent risks and the possibility of adopting a sort of exceptional measure are not the exclusive domain of public international law or of foreign investment law. The law of the World Trade Organization has specific provisions to address threats of material injury to domestic industries, such as Article 3.7 of the Anti-Dumping Agreement (ADA), Article 15.7 of the Agreement on Subsidies and Countervailing Measures (ASCM), and Article 4 of the Agreement on Safeguards (AS). There are some parallels worth highlighting. The threat of injury to the domestic industry of like products by the dumped or subsidized product must be foreseen and imminent. Thus, the mere possibility of injury is not sufficient for the imposition of anti-dumping duties or countervailing duties (Article 3.7 ADA and Article 15.7 (ASCM)). Evidence supporting the existence of the threat of injury and the causal link with the increase in imports for the purpose of imposing safeguard measures must be objective (Article 4 AS). 
or application of international law, be it non-precluded measures clauses or the customary rule of necessity. Apparently, the answer would be yes. Only once the majority or a consensus of economists and policy-makers have agreed on the merits of EWMs should their usefulness to the interpretation or application of international law be recognized. However, in this regard, it is worth recalling the words of Amos Oz, the Israeli writer, in A TALE OF LOVE AND DARKNESS:

Life is made up of different avenues. Everything can happen in one of several ways, according to different musical scores and parallel logics. Each of these parallel logics is consistent and coherent in its own terms in itself, indifferent to all the others.

The current world is one of parallel logics, as Amos Oz rightly and beautifully points out; thus, undisputed majorities and consensus are sometimes elusive. EWMs are not the exception, as has been illustrated. This being so, care has to be taken when requiring consensus or majoritarian views as a precondition for the use of the models in the interpretation of foreign investment law. In fact, such requirement should not exist.

Indeed, it is important to look at the law of the World Trade Organization to find inspiration to guide us on how EWMs could be used in the interpretation of international investment treaties or customary provisions. There, there is a familiarity with the use of science as a basis for the imposition of trade restrictions by Members. This is mainly the case with the Agreement on the Application of sanitary and phytosanitary measures and its Articles 5.1 and 5.2, according to which:

1. Members shall ensure that their sanitary and phytosanitary measures are based on an assessment, as appropriate to the circumstances, of the risks to human, animal or plant life or health, taking into account risk assessment techniques developed by the relevant international organizations.

2. In the assessment of risks, Members shall take into account available scientific evidence....

The WTO Appellate Body has made it clear that a majoritarian view among scientists is not a requirement for the lawfulness of the scientific bases of the sanitary or phytosanitary measures. When interpreting, specifically, Article 5.2, the WTO Appellate Body stated in European Communities-Measures Concerning Meat and Meat Products (Hormones):

$[\mathrm{T}]$ he risk assessment could set out both the prevailing view representing the 'mainstream' of scientific opinion, as well as the opinions of scientists taking a diverging view. Article 5.1 does not require that the risk assessment must necessarily embody only the view of the majority of the relevant scientific community... In most cases, responsible and representative governments tend to base their legislative and administrative measures on 'mainstream' scientific opinion. In other cases, equally responsible and representative governments 
may act in good faith on the basis of what, at a given time, may be a divergent opinion coming from qualified and respected sources.... 100

Underlying this Appellate Body's finding is the recognition of the parallel logics that $\mathrm{Oz}$ talks about. A similar approach should be taken by investor/State arbitration tribunals regarding the use of EWMs in the interpretation and application of international investment law despite the debate among economists on their value as a crisis prevention tool. ${ }^{101}$

The relevance of EWMs in the interpretation of international law should be linked to the principle of good faith. State policy-makers may choose to rely on EWMs and adopt measures aimed at preventing a crisis. If the given crisis is prevented but the measures adopted constitute violations of an international law obligation, the requirement of a serious threat would be met.

Finally, it is important to highlight that the use of econometric analysis is not a requirement under BIT non-precluded measures clauses or the customary rule of necessity, as is the use of science in the WTO SPS Agreement. This is an important difference. So, if under a stricter regime, as in WTO law, scientific majority is not required, there is no reason to request such majority regarding EWMs in international investment law, since this field of law affords States wider latitude regarding what kind of tools they can use to anticipate grave economic risks.

\section{B. Type of BIT violations that can be justified by non-precluded measures clauses based on EWMs}

An analysis of the effect of the successful invocation of BIT non-precluded measures clauses in light of the type of investors' rights adversely affected by the actions or regulations adopted by the host State reveals that the successful invocation of a BIT

100 Appellate Body Report, European Communities-Measures Concerning Meat and Meat Products (Hormones), WTO Doc. WT/DS26/AB/R, WT/DS48/AB/R, 16 January 1998, g 194, available at http://www.wto.org/english/tratop_e/dispu_e/hormab.pdf (visited 10 January 2014). As a result of this approach, WTO panels have accepted sanitary and phytosanitary measures supported by risk assessments based on divergent scientific opinions rendered by qualified and respected sources. In effect, the panel in European Communities-Measures Affecting the Approval and Marketing of Biotech Products stated:

Where a given risk assessment sets out a divergent opinion and this opinion comes from qualified and respected sources, it can be reasonably said that an SPS measure which reflects the divergent opinion is 'based on' the risk assessment in question inasmuch as the divergent opinion is expressed in that risk assessment.

WTO Panel Report, European Communities - Measures Affecting the Approval and Marketing of Biotech Products, WTO Doc. WT/DS291/R, 29 September 2006, g 7.3060, available at http://www.wto.org/english/tratop_e/dispu_e/cases_e/ds291_e.htm (visited 8 January 2014).

101 The parallels between WTO law and public international law and foreign investment law cannot go further to cover, for instance, methodological approaches. In effect, the use of methodologies to determine threat of injury to domestic industries of like or directly competitive products under WTO law cannot be of much use to determine the existence of a threat to an economy. The methods used in the application of WTO law rely on microeconomic analysis for a single product within a single country, whereas methodologies, such as EWMs, to determine threats to national economies rely on macroeconomic models involving multiple variables, usually related to several countries. 
non-precluded measures clause may exclude the unlawfulness of the majority of violations of the given BIT, as the CMS annulment committee pointed out, ${ }^{102}$ but not of all of them. This is also true regarding the successful invocation of BIT nonprecluded measures clauses based on EWMs for actions aimed at preventing unfolding economic crises.

The US-Argentina BIT may well serve to prove this particular point. Its Article IV(3) provides:

Nationals or companies of either Party whose investments suffer losses in the territory of the other Party owing to war or other armed conflict, revolution, state of national emergency, insurrection, civil disturbance or other similar events shall be accorded treatment by such other Party no less favorable that that accorded to its own nationals or companies or to nationals or companies of any other third country, whichever is the more favorable treatment, as regards any measures it adopts in relation to such losses. ${ }^{103}$

Article IV(3) is a provision that, without precluding or mandating compensation, deals with it under certain circumstances. It becomes applicable whenever any of such circumstances also serve as grounds for the successful invocation of Article XI, the non-precluded measure clause of this treaty. ${ }^{104}$

This is not to say that Article IV(3) only becomes relevant when there is a crisis covered by Article XI. Indeed, it is perfectly possible that an event of social disturbance, for instance, may not trigger Article XI but nonetheless prompt the application of Article IV(3). However, the opposite may be true in most cases: whenever a situation is covered by Article XI by involving issues of maintenance of public order, restoration of international peace, or protection of an essential security interest, the situation would trigger Article IV(3), since it may well be intimately related to any of the circumstances provided for in this provision.

Can it then be said that if, under a situation of emergency, Argentina or USA compensated domestic investors and not foreign investors, in clear violation of Article IV(3), such violation could be justified by Article XI of the BIT? Apparently, it could, since according to the test for the application of Article XI, a court and tribunal must first find a violation of the BIT and then proceed to determine whether the violation is justified under Article XI, and if so, the violation is excluded. However, a more detailed analysis of the effect of primary rules in the context of BITs shows that, although BIT non-precluded measures clauses have a broad scope to justify violations of a treaty, they cannot cover all, particularly violations of a

102 See CMS Decision on Annulment, supra note 94, 129.

103 Treaty Between the United States of America and the Argentine Republic Concerning the Reciprocal Encouragement and Protection of Investment, USA-Argentina, 14 November 1991, 31 I.L.M. 124.

104 Article X provides for:

This Treaty shall not preclude the application by either Party of measures necessary for the maintenance of public order, the fulfillment of its obligations with respect to the maintenance or restoration of international peace or security, or the Protection of its own essential security interests. 
provision like Article IV(3). ${ }^{105}$ Two kinds of rights underlie this situation: pre-crisis rights and crisis rights, defined as those acquired by foreign investors by virtue of the existence of the given emergency or disaster.

To begin with, the most common situation is one where foreign investors hold rights protected by the BIT prior to any circumstance covered by a BIT nonprecluded measures clause, which could be labelled pre-crisis rights. If the circumstance occurs and prompts the adoption of acts or regulations that adversely affect such rights, the clause can justify their violation. No compensation is then due by the host State for the amount of damage that investors bear as a result of measures adopted to face the given crisis.

But it is also possible for foreign investors to acquire new rights as a result of the crisis that impelled the invocation of the BIT non-precluded measures clause, if such a situation also falls under a provision similar to Article IV(3). For instance, if during the crisis, the host State compensated national investors to a certain extent and did not do the same for investors of a party to a BIT that included an analogous provision, these investors would acquire, by virtue of the crisis, a national treatment right regarding any compensation received by domestic investors. To be sure, this right may not be the same as the full compensation right that would exist if the violation had not been justified by the BIT non-precluded measures clause, and the right is restricted only to the compensation that national investors in similar circumstances received. ${ }^{106}$ In other words, it is a different kind of compensation based on a different legal ground.

The violation of this crisis right cannot be justified by the successful invocation of the BIT non-precluded measures clause, because it is the application of the clause itself that is one of the conditions for the existence of the right under Article IV(3), ${ }^{107}$ and it is not possible for the act that contributes to creating a right for the investor to also be the one that extinguishes it.

In the end, provisions like Article IV(3) constitute limitations on host States' actions under the specific factual situations provided therein, which also operate when any of these situations prompt the invocation of BIT non-precluded measures clauses.

Can it be said that precepts akin to Article IV(3) apply only when one of the factual situations provided therein takes place but not when any of them are prevented, as in the case of the prevention of economic crises? Such a narrow scope should be based on a complete interpretation of the given precept according to Articles 31-33 of the Vienna Convention. Although a detailed analysis of this topic is beyond the scope of this article, the author is inclined to suggest that, despite the fact that the text of Article IV(3), seen in isolation, appears to indicate that it does not cover losses associated with crisis prevention, an interpretation of this provision and others of similar content in light of context and the supplementary means of interpretation of a treaty seeking to protect foreign investment may end up offering enough bases

105 See Alvarez and Khamsi, supra note 93, 434.

106 For a similar argument, although grounded on a different basis, see Schill, supra note 93, 284. To be sure, the right is not that of obtaining exactly the same amount of money that domestic investors received, but of obtaining a sum that implies a treatment similar to that accorded to them. 
to conclude that the precept also covers events of losses resulting from measures aimed at preventing any of the above-mentioned events. Consequently, the violation of this kind of precept as a result of measures taken to prevent an economic crisis should not be justified by the successful invocation of a non-precluded measures clause based on EWMs.

\section{The use of early warning models in the interpretation of non-precluded measures clauses or the customary rule of necessity}

\section{The use of early warning models to detect grave and imminent economic perils}

In a very important statement, the Continental Tribunal suggested that measures adversely affecting foreign investors that are part of a policy aimed at preventing a crisis could be easily challenged. This would be so since it would be difficult to demonstrate the necessity of the given measure or action. ${ }^{108}$ But on the other hand, if no action is taken and the crisis unfolds, then tribunals would regard the omission as part of the contribution of the given State to the situation of necessity or to the crisis, again denying it the benefit of the excuse under customary international law or of the clause under international investment law, as the tribunal in Suez, Sociedad General de Aguas de Barcelona S.A., and InterAgua Servicios Integrales del Agua S.A.v the Argentine Republic did. The tribunal stated: 'Among Argentina's contributing factors to the crisis were... delays in responding to the early signs of the crisis ... ${ }^{, 09}$ In other words, prevention would not meet the necessity test, and lack of prevention would be later interpreted as a contribution to the situation of necessity.

The early warning literature should be used as the tool to avoid this trap. International tribunals should allow States to rely on EWMs to determine when there was a grave and imminent risk to their economies. ${ }^{110}$

108 When discussing certain measures that, according to the claimant, could have been adopted by Argentina to prevent its 2001 crisis, the Continental tribunal commented:

Such a pre-emptive or anticipatory default could have been more easily challengeable as to the absence of any "necessity" under the BIT.

Continental Award, supra note 94, 9229.

109 International Centre for Settlement of Investment Disputes, Suez, Sociedad General de Aguas de Barcelona S.A., and InterAgua Servicios Integrales del Agua S.A. v. the Argentine Republic, Decision on Liability, g 242. ICSID Case No ARB/03/17, 30 July 2010 [Suez Aguas de Barcelona Decision on Liability], available at http://italaw.com/documents/SuezInterAguaDecisiononLiability.pdf (visited 16 January 2014).

110 This situation would not take place regarding some BIT self-judging clauses, which constitute jurisdictional bars. However, not all BIT clauses may achieve this goal. It all depends on how their texts are interpreted in light of the principles of the Vienna Convention on the Law of Treaties. In addition, it is also important to take into account that it is up for international courts and tribunals to assess the scope of these clauses by virtue of their power to assess their own jurisdiction, so strict and flexible interpretations of these jurisdictional bars may well be expected. See Michael D Nolan and Frédéric G Sourgens, 'The Limits of Discretion? Self-Judging Emergency Clauses in International Investment Agreements', 3 Yearbook on International Investment Law and Policy 363, 364 (2010/2011) and Laurence Boisson de Chazournes, 'The Principle of Compétence de la Compétence in International Adjudication and its Role in an Era of Multiplication of Courts and Tribunals', in M Arsanjani, J Cogan and S Weissner (eds), Looking to the Future: Essays in Honor of W. Michael Reisman (Boston: Martinus Nijhoff Publishers, 2011) 1027. 
It is, though, important to qualify how EWMs work in practice. One has to take into account that economic policy should not be formulated on the basis of the use of a single EWM. Certainly, such situation is unlikely to take in place in reality. One might expect governments to make decisions on the basis of broader information, not a single EMW but several with different methodological approaches and indexes, ${ }^{11}$ in addition to any information that may come up from other sources, such as credit agencies' ratings and market participants. ${ }^{112}$ However, what one can expect is that States may sometimes rely mainly on the warnings provided for by EWMs mainly to adopt measures aimed at preventing severe economic crises.

In addition, it should not be required by tribunals that all the information point exactly in the same direction, in the sense that all crisis prevention instruments, EWMs, and non-model instruments, should converge on indicating the imminence of a crisis. This would be so because not all sources, such as credit-rating agencies' reports, are aimed at anticipating crises and not all market participants may be right regarding their information.

When the evidence is conflicting, it is up to international tribunals to determine whether they find the gravity and imminence of the given crisis proved or whether the crisis was not imminent but just probable, and therefore, the necessity justification or excuse must fail.

This conclusion raises a different but related issue: debates about faulty EWMs. The Reinhart/Rogoff error clearly illustrates that econometric models may have design faults, in terms of the chosen variables, their weighing, the countries included, the availability or reliability of the data used, among many others. A debate in litigation may exist regarding errors in the design or data of the EWMs on which a host State relied, whose purpose is to demonstrate that, owing to errors of these kinds, there was no such risk or the risk was neither grave nor imminent. ${ }^{113}$

This debate can certainly exist in investor/State arbitration, and decisions based on good faith errors in EWMs should be upheld by international tribunals. Crisis prevention is an important component of any kind of policy-making and is in itself costly, as will be seen below. ${ }^{114}$ Thus, requiring of States perfection as the standard

Summers, supra note 24

113 The situation is factually intensive, and its importance may depend on the specific circumstances of the case. It might not be that relevant when the host State relied on many EWMs, and errors are identified in one of them. In effect, the other EWMs and other sources may still provide a conclusion on the gravity and imminence of a crisis that is objective, coherent, and based on the data.

However, even if a host State relied on several EWMs, the debate may turn out to be relevant if the host State relied to a significant extent on the EWMs claimed by the investor to have errors.

$[\mathrm{N}] \mathrm{o}$ important policy conclusion should ever be based on a single statistical result. Policy judgements should be based on evidence accumulated from multiple studies done with different methodological approaches. Even then, there should be a reluctance to accept conclusions from 'models' without an intuitive understanding of what drives them. See infra text accompanying note 134 . 
of EWMs would certainly ignore the complexity of the operation of the State apparatus. $^{115}$

However, arbitration tribunals should set a limit: manifest errors in EWMs should not be permitted, in principle. However, even in such a case, sometimes caution is advised, and tribunals should not rush to conclude that a severe crisis was not imminent once they have found important errors in the given EWMs. Take the example of a State that decided to rely on a specific EWM that sent signals of an upcoming economic calamity when other EWMs and tools were not anticipating any. In this case, it cannot be easily said that all the host State had to do was to review the model that was sending warnings in order to detect any faulty features it might have. The fact is that the State facing this situation of conflicting warnings also knows that EWMs may also miss crises, so the State does not know which is the faulty EWM, and to clearly identify it, it has to review all of them. A tribunal should take into account the feasibility of such a review when determining whether the error contained in the EWM on which a State relied was so manifest as to conclude that the grave and imminent risk of a crisis did not exist. ${ }^{116}$

Generally, debates about the design of EWMs, either due to errors or to different economic views, should be handled by investment tribunals with a certain degree of deference to host States' economic bases for their conclusion that an economic crisis is imminent. Deference to the technical bases of States' decisions is not strange to investment arbitration. ${ }^{117}$ For instance, the NAFTA tribunal in Methanex $v$ U.S. dealt with the issue of whether a technical report detailing the risks of a chemical offered enough support for its ban on the sale and use. The tribunal pointed out that 'whilst

115 Although they referred to a standard of protection for investors, the words of the tribunal in Gami Investment Inc $v$ the Government of the United Mexican States are worth recalling, since these words are fully applicable to the situation discussed here. In effect, quoting the NAFTA award in S.D.Myers, the former tribunal stated:

\footnotetext{
When interpreting the 'minimum standard' a [NAFTA] Chapter 11 tribunal does not have an open-ended mandate to second-guess government decision making. Governments have to make many potentially controversial choices. In doing so, they may appear to have made mistakes, to have misjudges the facts, proceeded on the basis of a misguided economic or sociological theory, placed too much emphasis on some social values over others and adopted solutions that are ultimately ineffective or counterproductive. The ordinary remedy, if there were one, for errors in modern government is through internal political and legal process....
}

Original footnote: First Partial Award, op cit., note 8, para 261 (Note 8 states: 'First Partial Award of 13 November 2000, 8 ICSID Reports (forthcoming), at para 260 (2000).'

116 As has been seen, EWMs require massive amounts of data regarding different variables in many countries, which means that they are costly to maintain and, therefore, to review. As to the high maintenance costs of EWMs, see Bussière and Mulder, Early Warning Signals, supra note 36, 6.

117 See Yuka Fukunaga, 'Standard of Review and 'Scientific Truths' in the WTO Dispute Settlement System and Investment Arbitration', 3 Journal of International Dispute Settlement 559 (2012). Sometimes, and on the basis of domestic regulation, the standard of review of technical and economic matters by domestic courts may differ. In the European Union, the standard of review of the former is narrower than that of the latter. The Court of First Instance's ruling in Microsoft $v$ Commission [Case T-201/04, 2007. E.C.R. II-3601] is claimed to have made this distinction. See Lianos and Genakos, supra note 5, 56-57. No such distinction is made in BITs or in CIL, so the standard of review of technical issues, as defined by international investment arbitration, can equally be applied to economic matters. 
it is possible for other scientists and researchers to disagree in good faith with certain of its methodologies, analyses and conclusions, the fact of such disagreement, even if correct, does not warrant this Tribunal in treating [the report] as part of a political sham. ${ }^{118}$ Equally, the tribunal in Chemtura $v$ Canada coped with Canada's adoption of a regulation on canola seeds treated with a particular pesticide. The tribunal stated that its task was not 'to second-guess the correctness of the science-based decision-making of highly specialized regulatory agencies.'119 The tribunal limited its evaluation to whether Canada had acted in bad faith when carrying out the risk assessment on which it has based its regulation. ${ }^{120}$

Deference to the economic bases of the conclusion on the risk of a grave and imminent crisis does not mean deference to the conclusion itself, in the sense that investor/State tribunals should be deferential to the host State's perception of an upcoming crisis and its decision to prevent it. As in American administrative law, a deferential standard regarding technical bases does not preclude in-depth assessment of the government's decision by courts. ${ }^{121}$ Thus, arbitral tribunals should evaluate with rigour whether the conclusion as to the gravity and imminence of the given economic calamity is objective and coherent and has a sufficient basis in the available data of the EWMs. ${ }^{122}$

The use of EWMs also raises the question of the risk of their abuse to ground the prevention of economic crises and the adoption of measures adversely affecting foreign investors to this end. The approach suggested here would prevent such abuse. Mere reliance on EWMs should never be enough to demonstrate the existence of an upcoming economic crisis. The conclusion must strongly emerge from the models

118 Methanex Corporation v United States, Final Award on Jurisdiction and Merits (3 August 2005), pt III, ch A, $g$ 101, available at http://italaw.com/sites/default/files/case-documents/ita0529.pdf (visited 8 January 2014).

119 Chemtura Corporation v Canada, Award, 2 August 2010, g 134, available at http://italaw.com/docu ments/ChemturaAward_000.pdf (visited 8 January 2014).

120 See ibid, paras 146-63.

121 See Rahim Moloo and Justin M Jacinto, 'Standards of Review and Reviewing Standards: Public Interest Regulation in International Investment Law', 4 Yearbook on International Investment Law and Policy 539, 546 (2011-2012).

122 The WTO Appellate Body established these requirements of the scientific evidence to support an SPS measure, and the same logic should be used by international tribunals regarding the connection between the conclusion of the existence of an imminent risk and the given EWMs used as bases for such conclusion. See Appellate Body Report, Australia-Measures Affecting the Importation of Apples from New Zealand, WTO Doc. WT/DS367/AB/R, 29 November 2010, g 236, available at http://www.wto.org/ english/tratop_e/dispu_e/cases_e/ds367_e.htm (visited 8 January 2014).

It is worth highlighting that the use of econometric models for forward-looking purposes, as those used in merger cases, has been subject to what some authors claim to be a stricter standard of review by the courts of the European Union. See Lianos and Genakos, supra note 5, 58, citing Case C-12/03, Commission v Tetra Laval. [2005] ECR I-987. The courts have required of the assessments carried out by competition authorities not just descriptions of hypothetical anti-competitive behaviour, but specific analyses of the likely evolution of each of the markets in question. It is the present author's view that the standard of review suggested here of a host State's conclusion that there was a risk of a grave and imminent risk to its economy does not differ much in terms of the depth of the assessment of the government's decision that the European Court of Justice made in Commission v Tetra Laval. In effect, the standard of review recommended in this article is based on the evolution of specific economic variables over a certain period of time as shown by the given EWMs and not just on the hypothetical evolution of the variables. 
on the basis of data, coherence, and objectivity. Otherwise, the invocation of a nonprecluded measures clause should fail and full compensation be owed to investors. ${ }^{123}$

\section{Early warning models and the determination of a substantial contribution to the situation of necessity ${ }^{124}$}

Before proceeding with the analysis, it is worth mentioning that the assessment of this requirement or lack of substantial contribution by investor/State tribunals dealing with the Argentine crisis has sometimes included a list of the main causes, both internal and external, and from there the conclusion that Argentina's contribution was substantial or did not exist has just followed. For instance, the tribunal in National Grid P.L.C. $v$ Argentine Republic found that the Argentine crisis had been the result of several causes: internal policies that were under the control of Argentina and external shocks; the former 'created a fertile ground for the crisis to develop when in the late nineties the external factors ... came to play. ${ }^{125}$ On this basis, and although the tribunal had previously stated that both external and internal elements had contributed 'in significant part' to the crisis, ${ }^{126}$ the tribunal held that the contribution had been substantial and that the excuse of necessity had to fail. ${ }^{127} \mathrm{~A}$ similar

123 A related point is whether this approach is enough to prevent the abuse of crisis prevention based on EWMs and whether host States should also incur additional costs as a result of such potential abuse. It could be suggested, on the basis of WTO law, that retaliation could be an alternative in the form of a similar invocation of non-precluded measures clauses to avert an economic crisis by the State of the investor to justify measures against nationals of the first host State, which allegedly abused the clause. To the present author, the cost of retaliation of this sort seems to be unlikely to occur, for many reasons. First, it is difficult to imagine that the best alternative a State has to address the abuse of the other State party to a BIT is that of itself declaring the existence of an upcoming crisis. Crisis prevention is always costly in economic and political terms and a resort to it seems to be, for this reason, unlikely. Second, there will always be other diplomatic tools, much less costly, to address this specific concern of abuse of non-precluded measures clauses rooted in crisis prevention. Third, the retaliatory invocation of non-precluded measures clauses must itself meet the requirements of the clause, and the mere fact that a State party to a BIT is abusing the clause does not generally allow the other State party to invoke it. Such retaliatory invocation is likely to be unlawful. Retaliation is a valid tool in WTO law, not in foreign investment law.

This is not to say that States abusing the use of EWMs to adopt measures aimed at preventing an economic crisis and subsequently invoking the given BIT non-precluded measures clause to justify the violation of investors' rights would only incur the cost of compensating investors after international arbitration. The abuse of non-precluded measures clauses based on crisis prevention would, in most probability, increase the risk of investing in the abusing State, and investors would charge a premium to place their investment there. This is in itself an important additional cost that helps to deter the abuse of such clauses.

124 The requirement of lack of substantial contribution is specifically provided for in Article 25(2)(b) of the ILC's Articles and should also exist regarding BIT non-precluded measures clauses. For the detailed justification of this conclusion, see Alvarez-Jimenez, The Interpretation of Necessity Clauses in BITs, supra note 92, 441-42. National Grid Award, supra note 90, g 260.

Ibid.

See ibid. See also Suez, Sociedad General de Aguas de Barcelona S.A., and Vivendi Universal S.A. vs The Argentine Republic, (ICSID Case No. ARB/03/19), and AWG Group vs The Argentine Republic, Decision on Liability, 30 July 2010, g 264 [Suez Vivendi Decision on Liability], available at http://italaw.com/ sites/default/files/case-documents/ita0826.pdf (visited 10 January 2014); Impregilo Award, supra note 92, I 358; Suez Aguas de Barcelona Decision on Liability, supra note 109, g 242. 
reasoning, but reaching the opposite conclusion, was carried out by the Continental tribunal. $^{128}$

For the purpose of the application of the substantial State contribution requirement, it is then important to determine when an action or omission by a State can be regarded as a contribution to the given crisis. This section turns to evaluate how EWMs can be used by States and international tribunals when dealing with the requirement of lack of contribution to the situation of necessity.

The first way in which EWMs can be relevant for this purpose is to determine whether a State can lawfully claim that it did not contribute to a situation of necessity given the fact that its EWMs did not send any signal and missed the given crisis. As was seen above, EWMs may sometimes not include variables that may end up being determinant in bringing about a crisis, or the threshold of the variables was too high. No risk or threat was foreseen, the argument would go; thus, no omission took place at the time and in light of the available information, and therefore, no contribution took place in the form of lack of prevention of the crisis. ${ }^{129}$

The scrutiny of this justification should be assessed in light of the principle of good faith. Indeed, if the several EWMs with different methodologies and data do not send warnings, it is certainly reasonable for a State to claim that it could not have failed to prevent what it did not see coming. However, EWMs are not the only tools States have to assess the state of their economies. Consequently, the absence of warnings as a result of the use of EWMs should not always be conclusive. Assessments resulting from the information provided by market participants, and by the use of other analytical tools, should have been carried out. If these other tools also missed the crisis, there would be additional grounds to conclude that the State did not make a contribution by failing to prevent the crisis. But, if the other tools did anticipate the given crisis, a State should demonstrate why it did not pay heed to them and why it based its policy-making on the information furnished by its EWMs. Only after providing a reasoned ground for such conclusion should an international tribunal conclude that a State did not contribute to the situation of necessity by failing to prevent a crisis that its EWMs missed.

The second relevant situation is the assessment of the contribution to the state of necessity in the event in which a State did not act upon an EWM that repeatedly sent warning signals over several months. ${ }^{130}$ A warning may be sent, but this does not mean that political actors will react to it. Such reactions depend on the incentives and limitations that policy-makers may face at a particular moment. ${ }^{131}$ For instance, a government may not have a majority in elected bodies to ensure the passing of

See Continental Award, supra note 94, g 236.

The fact that a tribunal declared that a State did not fail to prevent a crisis and, therefore, such failure cannot be regarded as a specific contribution to the situation of necessity, as important as it is, would not always prevent a tribunal from concluding that in general, a State substantially contributed to the given crisis. This would be so because a failure to prevent would be just one of the possible contributions, in the form of omissions, but there might have been others, particularly measures or actions, that could have prompted the economic calamity in question and led the tribunal to the said general conclusion.

Recall that EWMs are now designed to send warning signals with a lag of several months, in many cases one year, so policy-makers can react and prevent the potential crisis.

See Bussière and Mulder, Early Warning Signals, supra note 36, 7. 
legislation, which may make the prevention of the crisis much more difficult to achieve. ${ }^{132}$ On the other hand, political consensus to adopt preventive measures and avoid a still non-visible crisis may be elusive, since some political actors may not regard the risks as credible or sufficient to introduce new legislation, costly in political terms. ${ }^{133}$ As Bank of Canada researchers state:

Taking no action is costly when a financial stress is nearing, but so is taking action when a financial event is not impending. ${ }^{134}$

On these bases, did the given State contribute to the crisis by failing to prevent a crisis whose emergence it noticed in advance? To be sure, the answer to this question would be factually intensive and depend on many circumstances: how much in advance the EWMs anticipated the crisis, whether other crisis prevention instruments did not detect it, what explains the lack of action or of sufficient action on the part of the State, among others.

However, whenever different EWMs coincide in anticipating a crisis several months in advance and the State is still unable to prevent it, international tribunals should, in principle, recognize that its omissions substantially contributed to the situation. The quoted words of the Suez Aguas de Barcelona tribunal would apply neatly. ${ }^{135}$

\section{Crisis prevention based on the use of early warning models and the different interpretative approaches to some of the requirements of Article 25 of the ILC's articles}

The customary rule of necessity establishes as one of the requirements for its successful invocation the uniqueness of the measure or action to achieve the goal of addressing the risk to the essential interest. In other words, other alternatives to complying with the international obligation in question were not available to protect the interest.

The Continental tribunal held that a significant margin of appreciation should be allowed to States facing critical situations, since it is not the time for nice judgments, particularly when examined by others with the disadvantage of hindsight'. ${ }^{136}$ The present author shares this perspective, in light of the significant costs of varied character that economic crises bring to States, societies, and individuals. However, it is also important to caution that this deference cannot be unfettered, because it would make the customary excuse widely available, which contradicts its exceptional nature and strict interpretation.

136 Continental Award, supra note 94, 9 181. It is important to recall that the Continental tribunal was assessing the requirement of uniqueness not on the basis of the customary rule, but on the basis of a BIT necessity clause interpreted in light of WTO law, where this requirement exists. The quoted statement, though, perfectly applied to the identical requisite under the customary rule. 
So, a mixture of deference and strictness seems to be sound when international tribunals interpret some of the requirements of Article 25, in general, when a State adopts measures to prevent an economic crisis that violates international obligations. In this case, the requirement of graveness and imminence should be assessed with the deference criterion, within the terms mentioned above, since it is important to endow States with the powers to avoid the economic, social, and political losses associated with these events. However, courts and tribunals should take a stricter stance regarding the evaluation of the uniqueness of the measures, under Article 25(1)(a), in the said circumstance. ${ }^{137}$ In effect, regarding this requirement, governments should expect a strict evaluation by international tribunals as to why such prevention was not carried out with a measure that did not violate an international law obligation. It would be expected that States, in their pursuit of avoiding a crisis and when they were not still facing the economic, social, and political costs associated with the fragmentation of societies and elites, had enough instruments to achieve this goal without having, in principle, to take actions contrary to their international obligations.

The mixture of deference and lack thereof to governments by international courts in the interpretation of the various requirements of a single international law provision, whose texts do not call for them, seems to be an oddity. However, it is a valid approach rooted in a sound policy: the legitimacy of international adjudication and its ability to settle international disputes. Indeed, it is one thing for an international tribunal to declare that a government failed in its customary defence because the imminence or gravity of the risk did not exist, a pronouncement that goes to the heart of what governments are meant to do, to protect their economies and citizens. It is quite another to declare that the defence failed because the State had other means to achieve the prevention other than through the violation of an international obligation. Domestic opposition to the award may be higher towards the former than towards the latter decision.

137 The uniqueness requirement has been an important obstacle for the successful invocation of the customary excuse of necessity in the case law stemming from the Argentine crisis. For instance, the Suez Vivendi tribunal declared that Argentina had other means available but failed to identify them, which it should have done (see Suez Vivendi Decision on Liability, supra note 127, g 260). The Total tribunal declared that Argentina had not demonstrated that it did not have other available means other than the illegal measure to deal with the crisis (see Total Decision on Liability, supra note 92, g9 223-34). The conclusion rested mostly on the allocation of burden of proof of the requirement, which fell on Argentina, and on the fact that the investor had identified two alternative means that could have been used, without Argentina having responded to prove why they were not available (see Total Decision on Liability, supra note 92, 9 223; see also ibid, 9 345). The tribunal in Suez, Sociedad General de Aguas de Barcelona S.A., and InterAgua Servicios Integrales del Agua S.A. $v$ the Argentine Republic also found the existence of alternative means to achieve the same result sought by the adopted measures in violation of the BIT. However, the real availability of these means was not analyzed. See Suez Aguas de Barcelona Decision on Liability], supra note 109, 9238.

A model to follow in the evaluation of the uniqueness requirement is that carried out by the Continental tribunal, regardless of its conclusion on this point. The tribunal assessed each of the suggested alternatives in detail and in practical, not hypothetical, terms. For instance, alternatives that had been tried and failed to prevent the crisis were not regarded as available for the purpose of the uniqueness requirement, and neither were those whose costs were much higher than those of the adopted measures (see Continental Award, supra note 94, 9 g 209-14). 
Given that the result is the same in both cases-the failure of the necessity defence-there is then a policy reason to adopt a scheme of interpretation of the different requirements of the necessity exception that brings about the lesser institutional costs for the international adjudicator, not to mention the more favourable conditions for settlement that a decision based on such approach engenders.

A similar approach can exist regarding the interpretation and application of nonprecluded measures clauses, some of which might not include the uniqueness requirement. Investor/State tribunals should adopt a deferential approach to the evaluation of the technical bases of the imminence of the crisis and a strict approach regarding other requirements, such as the nexus between the measure and the crisis in question. ${ }^{138}$

Jose Saramago in La Lucidité cannot better define the approach suggested here:

la nécessité... d'un équilibre destine à maintenir l'univers sur ses rails et les planètes sur leur trajectoire commande que chaque fois que l'on retire quelque chose d'un coté l'on ajoute quelque chose de plus o mois équivalent de l'autre... 139

\section{Other uses of early warning models in the interpretation of BIT non-precluded measures clauses or the customary rule}

In addition to serving as a tool to determine when a crisis is about to take place, EWMs can play an additional and very important role. Referring to continuous EWMs, European Central Bank researchers argue that these models 'are particularly useful to determine when a crisis started and ended...., ${ }^{140}$

The date of the end of a crisis is not clear-cut, as the Great Recession evidences, and Churchill's words may portray well this difficulty, even quoted out of context: 'It is not the end, it is not the beginning of the end, it is maybe the end of the beginning.' The difficulty regarding the definition of the ending of a crisis is also well illustrated by the fact that the same 2001 Argentine crisis ended at different times for several tribunals. ${ }^{141}$

Perhaps, to avoid this problem, some international tribunals have adopted a different approach when applying both a BIT non-precluded measures clause and the customary rule: they have assessed whether the State was facing a grave and imminent risk to the economy at the time it adopted the measure contrary to international law.

Moloo and Jacinto hint at this point, although not in the context of the analysis carried out here. See Moloo and Jacinto, supra note 121, 567.

139 ' $\mathrm{t}$ ] he oft-invoked need for balance which has kept the universe on track and the planets on course means that whenever something is taken from one side, it is replaced by something else on the other...' See Babecký et al., supra note 15,7 .

141 The duration of the Argentine crisis was much shorter for the LG\&E tribunal than for the CMS tribunal. For the former, it ran from 1 December 2001, until 26 April 2003, while for the latter, it ran from 17 August 2000, to some time at the end of 2004 or beginning of 2005. See LG 6 E Decision on Liability, supra note 95, 99 226-29; CMS Gas Transmission Co. v Argentine Republic, Award, ICSID Case No. ARB/01/8, 12 May 2005, 9 g 250, 441, available at: http://icsid.worldbank.org/ICSID/ FrontServlet?request Type $=$ CasesRH\&actionVal $=$ showDoc\&docId $=$ DC504_En\&caseId $=C 4$ (visited 13 January 2014). 
For instance, the Total tribunal, deciding the necessity defence under the customary rule, also refused to excuse a violation of the given BIT, because Argentina had carried out the actions in question on 11 August 2004, when it was not facing a grave and imminent peril. ${ }^{142}$ A slightly different approach was adopted by the Continental tribunal. It declared that a swap of Treasury Bills (Argentine Government Treasury Bills (LETE)) against new securities on 9 December 2004, which were rejected by the claimant, since the offer meant that the investor would receive in exchange just US\$0.30 per dollar, ${ }^{143}$ was offered 'when Argentina's financial conditions were evolving towards normality'. ${ }^{144}$ The reason for this evolution was the fact that Argentina had re-entered the international financial market in September 2004. ${ }^{145}$

Determining when a given crisis ends is a very important decision for the purpose of international investment law and has quite important consequences for host States and investors. First of all, the date of the end of the crisis sets a limit to host States' ability to adopt measures that affect investors. Measures subsequently enacted will not get the benefits of the BIT clause or the customary rule. Additionally, and from the investor's perspective, the end of the given crisis means that compensation is fully owed to it by the host State afterwards, even if the necessity excuse under CIL is successful due to its temporary character. ${ }^{146,147}$

Economic fundamentals may not return to pre-crisis levels at the same time, and a decision must be made regarding which indicators must be chosen to conclude that an economic crisis has ended. While an answer to the issue of the end of a crisis is factual and specific and should be made on a case-by-case basis, it is possible to simply say that the closer the fundamentals of the given economy are to their historical trends, the less imminent and grave the risk is. In fact, once this return is shown, the risk may have well become just probable, to use the ICJ's words, and, therefore, outside the scope of BIT non-precluded measures clauses or the customary rule.

However, this conclusion has to be seen in light of what Bussière has identified, in the sense that there is a risk after a currency crisis of a new one. In his words, 'Vigilance must not decrease after a first (currency) crisis has happened as it may be followed by another crisis soon after. ${ }^{, 48}$ Consequently, the conclusion that an economy was on the path of recovery at a certain time can be reached only once the risk

142 See Total Decision on Liability, supra note 92, 99 337, 345. The Total tribunal did not offer any ground for this conclusion, in part because the measures and omissions were not proven by Argentina to be connected to any essential interest. See ibid, $\mathbf{9} 345$. Ibid, $\mathbf{9} 221$.

See ibid, 9 159. Further evidence of the recovery was that Argentina had repaid all amounts outstanding to the IMF in 2005 and January 2006. See ibid, 159.

In this regard, the ICJ stated in Gabcikovo-Nagymaros that '[a]s soon as the state of necessity ceases to exist, the duty to comply with treaty obligations revives'. See Gabcikovo-Nagymaros, supra note 92, $\mathbf{g}$ 101.

The end of the crisis has not had the same effect when BIT non-precluded measures clauses are applicable to the dispute. According to the Continental tribunal, for instance, the justification afforded by the clause at issue meant that no compensation was ever due to investors. See Continental Award, supra note 94, 99266,304 . To be sure, the same cannot be said regarding violations of a BIT brought about after the crisis ended, in which case compensation from the time of the adoption of the measure is due to the investor. See Continental Award, supra note 94, 9305.

Bussière, How Early Were the Warning Signals, supra note 17, 1603. 
of a revival of the crisis at the time of adoption of the measure in question has been evaluated and discarded. This is to say that looking only at the positive performance of the given economy in the recent past should not necessarily be enough to arrive at the said conclusion.

It is certainly up to international tribunals to make the determination as to when a crisis ended or when there is no longer a risk over the given economy. ${ }^{149}$ They enjoy significant latitude to choose the economic fundamentals or factual situations on which to ground such conclusion. However, EWMs can be used to offer a more reasoned decision since, in particular, out-of-sample EWMs continue to send warning signals that there is a risk of a crisis or that there is an ongoing crisis, until the model no longer sends warnings, a moment that marks the end of the risk or of the calamity. Thus, for instance, if a host State relied on EWMs to successfully prevent a crisis, the very same EWMs could be used to determine when the grave and imminent risk disappeared. ${ }^{150}$ The given host State would not be able to claim the benefit of a BIT necessity clause or of the customary rule for measures contrary to international obligations adopted after a date for which its own EWMs did not see any risk. $^{151}$

\section{CONCLUSION}

The present article has illustrated the extraordinary costs of economic crises in terms of increasing unemployment, decline of housing prices, equity prices and tax revenue, fall of GDP, and raise of government debt over several years. It does not come as a surprise that States and international financial institutions are developing economic models, paramount among them EWMs, aimed at detecting these costly events.

The article has presented a description of the different kinds of EWMs, the challenges modellers face regarding the choice of the relevant variables, the availability and reliability of data, and how EWMs should be used in practice by States as a policy-making tool. The article has also illustrated that EWMs have performed in the past much better than other instruments also used to anticipate economic crises of any sort, such as pure guess research and non-model-based forecasts, namely, agency ratings and private analysts rating currency risks.

However, not all economists agree on the usefulness of EWMs, and the article has shown the main criticisms that EWMs have received and the scepticism around their value as a crisis prevention instrument. Despite such objections, and even with their

149 To be sure, a crisis should not just be regarded to have ended once all the economic fundamentals have returned to their pre-crisis level, since at this time, not only is there not a probable risk of crisis over the economy, but there is no risk at all.

150 However, this is not to say that EWMs may always furnish a clear and unequivocal date of the end of the risk of a crisis or of the end of the crisis in a way that makes international arbitral tribunals' judgment unnecessary. As was seen, governments may rely on more than one EWM with different methodologies and data, so they may have not stopped sending warnings at the same time, and a decision based on judgment must be made as to what this date is. However, in such an event, the use of EWMs may be the guiding element in making such determination.

151 There might be occasions, though, in which particular EWMs might not be useful for the purpose of determining the end of a crisis. For instance, it is clear that an EWM that missed a crisis cannot be lately used to determine when this ended. 
limitations, EWMs are a good substitute for judgment-based assessments and may serve to narrow the possibility of crisis denial in order to evade political costs. In any case, EWMs are here to stay, since important improvements to their design may be expected as a result of the significant amount of resources devoted to them in the aftermath of the Great Recession.

In addition to the economics of EWMs, this article has discussed the role that they may play in the interpretation and application of BIT non-precluded measures clauses and the customary rule of necessity. The starting point of the article in this regard is that, drawing on WTO law, the lack of consensus among economists on the usefulness of EWMs should neither prevent the said role nor dilute its importance.

Delving into such a role, the article has illustrated three main dimensions. First, there is the value that EWMs may have in proving the existence of a grave and imminent risk to economies for the purpose of the invocation of the given non-precluded measures clause or the customary rule. The article has suggested in this regard that, despite the existence of diverse views on EWM design, international arbitration tribunals should be deferent to the economic bases in EWMs of a State's conclusion that a crisis is upcoming and that measures are required to prevent it. The article has shown that such deference is not totally strange to investor/State arbitration and that it does prevent arbitration tribunals from carrying out a rigorous assessment on whether the State's conclusion as to the gravity and imminence of the given economic calamity is objective and coherent and has a sufficient basis in the available data of the EWMs.

The second dimension is related to the requirement of lack of contribution to the situation of necessity under Article 25(2)(b), which requirement may also exist under BITs non-precluded measures clauses. This article has shown under which conditions EWMs can be used by States to demonstrate that they did not contribute to the given crisis by failing to prevent it, when their EWMs missed the given crisis and did not send warnings. Furthermore, international arbitration tribunals may face the case of States that did not act upon the warnings sent by their EWMs and are invoking a BIT non-precluded measures clause or the customary rule. The article argues that whenever different EWMs coincide in anticipating a crisis and the given State was still unable to prevent it, international tribunals should, in principle, declare that its omissions substantially contributed to the crisis.

The third and final dimension of EWMs is the use arbitration tribunals may make of them to determine the end of crisis. The article has shown that tribunals dealing with the Argentine calamity have had diverse views on when it ended, and their decisions in this regard have been based mainly on pure judgment. EWMs could provide tribunals with more solid grounds to determine such a date as to future economic calamities.

'Les crises aggravent les incertitudes, favorisent les interrogations; elles peuvent stimuler la recherche de solutions nouvelles...' says the French philosopher Edgar Morin, commenting on the Great Recession. The latter has prompted new developments in economics, and international investment law and adjudication should draw on them to evolve. This article has sought to make a contribution in this direction. 


\section{ACKNOWLEDGEMENT}

The author is grateful to Carlos Arango (Banco de la República, Colombia), Jan Babecký (European Central Bank), and Fuchun Li (Bank of Canada) for their valuable help with some practical aspects of the operation of early warning models, and two anonymous peer reviewers for their important comments on earlier drafts of this article. The usual disclaimer applies. This article is dedicated to Eliana Herrera, Leticia and Valeria Aluna Alvarez. To Concha Jimenez in memoriam. 